\title{
GLUCAGON-INDUCED HYPERGLYCEMIA AS AN INDEX OF LIVER FUNCTION 1, 2
}

\author{
By THEODORE B. VAN ITALLIE ${ }^{3}$ AND WILLIAM B. A. BENTLEY \\ (From the Department of Medicine, St. Luke's Hospital, New York, N. Y.)
}

(Submitted for publication June 15, 1955; accepted August 17, 1955)

Glucagon is a protein substance in pancreatic extracts which raises blood glucose by stimulating hepatic glycogenolysis (1-3). For this reason, it has been termed the hyperglycemic glycogenolytic factor (HGF) of the pancreas. Sutherland and Cori (2) have shown that glucagon increases the concentration of active phosphorylase in liver slice preparations. Apparently, glucagon administration does not induce glycogenolysis in muscle $(4,5)$.

Whether glucagon has an effect on extrahepatic utilization of glucose is still a matter of controversy. Drury, Wick, and Sherrill (6) have reported that the rate of uptake of $\mathrm{C}^{14}$-labeled glucose by eviscerated-nephrectomized rabbits actually decreases when glucagon is administered to such animals. On the other hand, Root, Ellis, and Staub (7), using intact rabbits and mice, have demonstrated that the presence of glucagon in insulin solutions in ratios of from $1: 100$ to $1: 1$ does not influence the degree of hypoglycemia produced by insulin and does not alter the potency of the insulin preparation as determined by the mouse convulsion assay. Ingle, Nezamis, and Humphrey (8) were unable to demonstrate any influence of glucagon upon extrahepatic glucose utilization in eviscerated rats. Using peripheral arteriovenous glucose differences as an index of peripheral glucose utilization in healthy human subjects, Van Itallie, Morgan, and Dotti (9) have found that glucagon does not inhibit and may accelerate uptake of glucose by peripheral tissues.

It has been known for many years that the diseased liver usually does not contain a normal quantity of glycogen. Brill and Fitz-Hugh (10)

1 This investigation was supported by a grant from Eli Lilly and Co., Indianapolis, Indiana, and by the Clark Fund.

2 Presented in part before the 126th National Meeting of the American Chemical Society, New York City, September 17, 1954.

3 Present address: Harvard School of Public Health, Boston, Massachusetts. and Loeb, Reeves, and Glasier (11) reported that the hyperglycemic response to a standard dose of epinephrine in patients with hepatic disease is well below normal. However, injection of epinephrine has serious disadvantages as a means of estimating liver glycogen content. In doses needed to produce a maximal hyperglycemic response $(1.0 \mathrm{mg}$. or more), epinephrine administration frequently is associated with such side effects as headache, dizziness, and palpitation. Cardiac arrhythmias and cerebral hemorrhage, although rare complications, have occurred following epinephrine injection (12). Because of its potential toxicity epinephrine is almost always administered subcutaneously or intramuscularly, and the rate at which it enters the circulation from such sites is necessarily variable. Thus, the time at which its maximal hyperglycemic effect can be measured is uncertain.

In contrast, glucagon exerts a more potent glycogenolytic effect on liver, on a molecular basis, than does epinephrine (13), and is without reported toxic side effects, even when administered intravenously in large amounts. Because of these apparent advantages of glucagon over epinephrine, an attempt has been made to determine whether glucagon-induced hyperglycemia constitutes a potentially useful index of liver function.

\section{PROCEDURE}

Ten healthy graduate students and eight patients with severe parenchymal liver disease served as subjects. All subjects were in the postabsorptive state at the time of study. Diagnoses of the patients and results of liver function tests are in Table I. The glucagon (Lilly No. 208-158B-214) 4 used in the study was prepared by the method of Staub, Sinn, and Behrens (14). It was highly purified, containing only 0.005 to 0.05 unit of insulin per mg. glucagon. The material employed was of uniform potency.

The glucagon was administered intravenously in approximately $150 \mathrm{ml}$. isotonic sodium chloride solution at

4 Supplied through the courtesy of Dr. W. R. Kirtley of Eli Lilly and Company, Indianapolis, Indiana. 
TABLE I

Patients with hepatic disease: Results of liver function tests

\begin{tabular}{|c|c|c|c|c|c|c|c|c|c|}
\hline \multirow[b]{2}{*}{ Patient } & \multirow[b]{2}{*}{ Diagnosis } & \multirow{2}{*}{$\begin{array}{l}\text { Thymol } \\
\text { turbidity } \\
\text { (units) }\end{array}$} & \multirow{2}{*}{$\begin{array}{l}\text { Cephalin } \\
\text { flocculation }\end{array}$} & \multirow{2}{*}{$\begin{array}{c}\text { Alkaline } \\
\text { phosphatase } \\
\text { (Bodansky } \\
\text { units) }\end{array}$} & \multirow{2}{*}{ 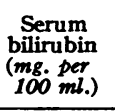 } & \multirow{2}{*}{$\begin{array}{c}\text { Serum } \\
\text { albumin } \\
(\mathrm{gm} . \mathrm{per} \\
100 \mathrm{ml.})\end{array}$} & \multirow{2}{*}{$\begin{array}{c}\text { Serum } \\
\text { globulin } \\
\text { (gm. per } \\
100 \text { ml. })\end{array}$} & \multicolumn{2}{|c|}{$\begin{array}{c}\text { Bromsulfalein } \\
\text { retention }\end{array}$} \\
\hline & & & & & & & & 15 min. & $45 \mathrm{~min}$. \\
\hline H. R. & $\begin{array}{l}\text { Laennec's cirrhosis } \\
\text { of liver }\end{array}$ & 13.7 & ++++ & 7.6 & 4.0 & 3.8 & 4.9 & $\begin{array}{l}\% \\
63\end{array}$ & $\begin{array}{c}\% \\
40\end{array}$ \\
\hline G. F. & Laennec's cirrhosis & 4.9 & ++++ & & 0.4 & 4.4 & 2.9 & & 23 \\
\hline E. E. & $\begin{array}{l}\text { Laennec's cirrhosis } \\
\text { of liver }\end{array}$ & 5.7 & ++ & 15.1 & 39.2 & 2.8 & 6.6 & & \\
\hline A. $\mathrm{G}$. & $\begin{array}{l}\text { Homologous serum } \\
\text { hepatitis }\end{array}$ & 9.7 & ++++ & 7.1 & 17.3 & 4.2 & 3.3 & 21 & 10 \\
\hline J.F. & $\begin{array}{l}\text { Laennec's cirrhosis } \\
\text { of liver }\end{array}$ & 2.6 & +++ & 5.7 & 5.6 & 2.8 & 4.1 & 49 & 21 \\
\hline $\begin{array}{l}\text { H. C. } \\
\text { A. C. }\end{array}$ & $\begin{array}{l}\text { Infectious hepatitis } \\
\text { Laennec's cirrhosis } \\
\text { of liver }\end{array}$ & $\begin{array}{l}4.4 \\
4.9\end{array}$ & $\begin{array}{l}++++ \\
+++\end{array}$ & $\begin{array}{l}10.6 \\
12.0\end{array}$ & $\begin{array}{r}12.8 \\
3.6\end{array}$ & $\begin{array}{l}5.4 \\
2.7\end{array}$ & $\begin{array}{l}3.9 \\
3.9\end{array}$ & $\begin{array}{l}32 \\
61\end{array}$ & $\begin{array}{l}13 \\
38\end{array}$ \\
\hline M. G. & $\begin{array}{l}\text { Laennec's cirrhosis } \\
\text { of liver }\end{array}$ & 6.9 & $\mathbf{0}$ & 7.2 & 3.6 & 4.1 & 3.8 & 64 & 46 \\
\hline
\end{tabular}

a constant rate by means of a Bowman constant infusion pump. Duration of infusions was approximately 30 minutes. $^{5}$ The dose of glucagon in every instance was $0.03 \mathrm{mg}$. per $\mathrm{Kg}$. body weight.

In the normal subjects, control capillary and venous blood samples were obtained virtually simultaneously immediately prior to glucagon administration, at the end of glucagon infusion, and at 25-minute intervals for approximately 75 minutes thereafter. In patients with liver disease the same schedule was followed except that capillary blood samples were not taken.

On a second occasion, the experimental procedure was repeated in all normal subjects and patients except that synthetic epinephrine (Suprarenin (8) ${ }^{6}$ was administered subcutaneously 10 minutes prior to glucagon infusion. The dose of epinephrine was $0.003 \mathrm{mg}$. per $\mathrm{Kg}$. body weight. In such instances, control glucose samples were obtained immediately prior to epinephrine administration.

In a third series of experiments, six of the normal subjects were given $0.003 \mathrm{mg}$. per $\mathrm{Kg}$. synthetic epinephrine subcutaneously. In this group, capillary and venous glucose levels were determined before and at frequent intervals for approximately 100 minutes following epinephrine injection.

For three days prior to each experiment, each subject was kept on a diet providing at least $250 \mathrm{gm}$. of carbohydrate per day (15). Glucose in whole blood was measured by the method of Somogyi $(16,17)$, as modified by Nelson (18). Venous blood samples were obtained with a minimum of stasis from an antecubital vein, and almost simultaneously, capillary blood (which has the

5 Later studies have shown that prolonged injection of glucagon is not necessary. Comparable hyperglycemic responses can be induced when the same amount of glucagon diluted in $10 \mathrm{ml}$. saline is injected rapidly by syringe.

- Supplied through the courtesy of Dr. A. Scribner, Winthrop-Stearns, Inc., New York, New York. same glucose concentration as arterial blood [19, 20]) was collected by direct pipetting from a finger tip of the same extremity after cutaneous puncture. Determinations were done in duplicate on $0.2 \mathrm{ml}$. samples.

To permit comparison of peripheral glucose uptakes in the presence of differing capillary glucose levels, relative assimilation indexes (R.A.I.) were calculated for each experiment in which capillary-venous glucose differences were measured, according to the formula of Somogyi (21) :

$$
\text { R.A.I. } \frac{100 \times \Sigma(C-V)}{\Sigma(i)} \text {, }
$$

where

$$
\begin{aligned}
\Sigma(C-V)= & \text { assimilation index }=\text { sum of the capillary } \\
& \text { venous differences } \\
\Sigma(i)= & \text { hyperglycemic sum = sum of the incre- } \\
& \text { ments in capillary blood glucose over the } \\
& \text { control level during the corresponding time } \\
& \text { interval. }
\end{aligned}
$$

(Negative increments and their corresponding C-V differences were omitted from the calculations and negative $\mathrm{C}-\mathrm{V}$ differences associated with positive increments were assigned a value of zero.)

\section{RESULTS}

A typical hyperglycemic response to intravenous glucagon in a normal subject is shown in part A of Figure 1. The capillary and venous glucose values rise rapidly during glucagon infusion and fall rapidly after the end of glucagon administration to levels below initial, control values. Appreciable capillary-venous ( $\mathrm{C}-\mathrm{V}$ ) differences are maintained on the falling segment of the curve, indicating removal of glucose by peripheral tissues. 
In part $B$ of Figure 1 is shown the modification of the capillary-venous glucose pattern which occurs when $0.003 \mathrm{mg}$. per $\mathrm{Kg}$. synthetic epinephrine is administered subcutaneously 10 minutes prior to intravenous administration of the same quantity of glucagon to the same subject for approximately the same time interval. In this instance, the glucagon-induced hyperglycemia is augmented and the venous and capillary glucose levels at all points of the curve are close together.

In part $\mathrm{C}$ of Figure 1 is shown the hyperglycemic response of the same individual to 0.003 mg. per Kg. synthetic epinephrine given subcutaneously. Capillary-venous glucose differences remain negligible throughout.

Capillary and venous increments over control values in the normal subjects following administration of (a) glucagon alone, (b) epinephrine and glucagon together, and (c) epinephrine alone, are given in Table II. The relative assimilation indexes (R.A.I.) calculated for each subject are also in Table II.

Comparison of the means of the relative assimi- lation indexes shows that epinephrine administration, either alone or in combination with glucagon is associated with a significantly lower index of glucose assimilation than that which occurs when glucagon alone is administered $(p<0.01)$.

Venous increments over control values in the patients with liver disease following administration of (a) glucagon, and (b) glucagon and epinephrine conjointly, are given in Table III. In contrast to the findings in the normal subjects, use of epinephrine in conjunction with glucagon in the patients with liver disease does not result in a greater mean rise in blood glucose than that induced by glucagon administration alone.

In Figure 2, the means of the hyperglycemic responses (venous blood) to glucagon alone of the normal subjects and of the patients with liver diseases are compared. The configuration of the curve representing the mean response of the normal group is similar to that displayed by the single normal subject depicted in Figure 1A. Again, the appreciable secondary hypoglycemia following the hyperglycemic phase is evident.

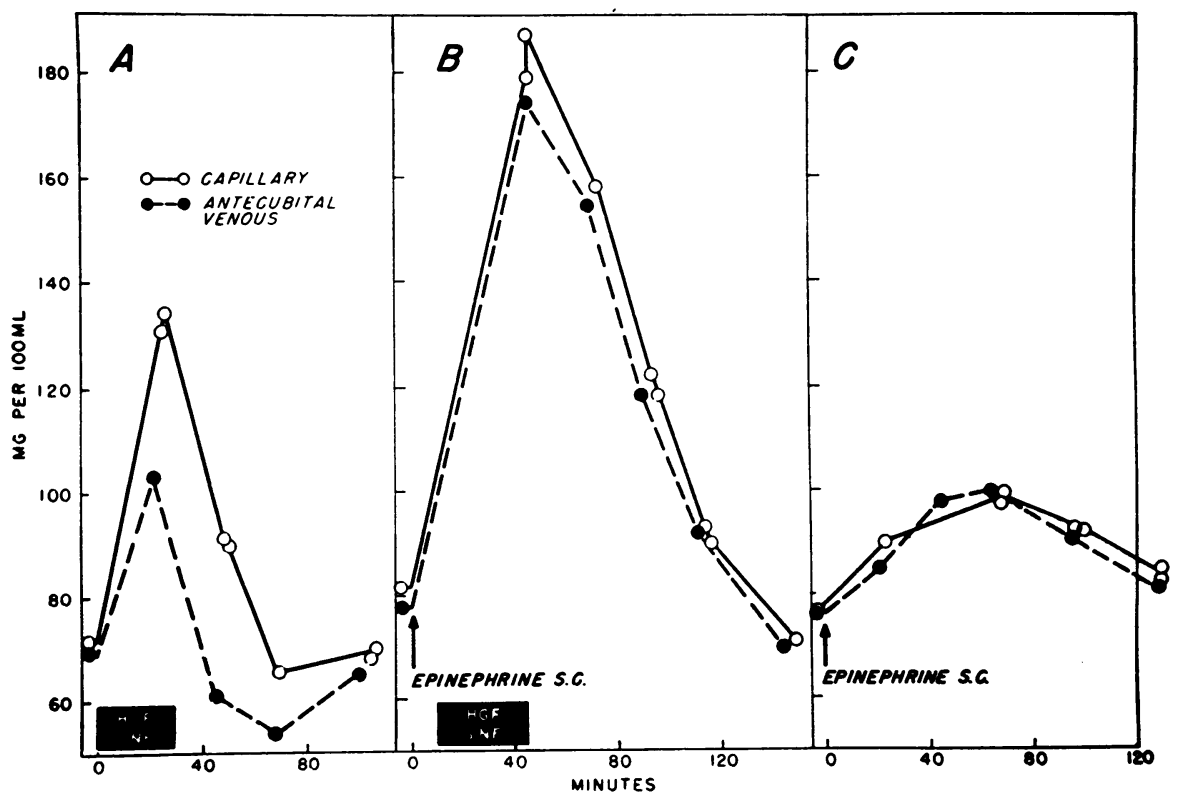

Fig. 1. (Subject J. G.) A. Glucagon-Induced Hyperglycemia in a Normal Subject, with Large Capillary-Venous (C-V) Differences Maintained on the Falling Limb of the Curve (2.1 mg. of Glucagon in Saline Given by Constant Infusion). B. Accentuation of Glucagon-Induced Hyperglycemia and Diminution of C-V Differences During Administration of 2.1 mg. Glucagon by Constant Infusion Preceded by Subcutaneous Injection of 0.20 Mg. of Epinephrine. C. Effect on Glucose Levels and Pattern of C-V Differences of 0.20 mg. EpiNEPHRINe INJeCted Subcutaneously 
TABLE II

Effect of glucagon alone, glucagon and epinephrine together, and epinephrine alone on capillary and venous glucose levels in normal subjects

\begin{tabular}{|c|c|c|c|c|c|c|c|c|}
\hline \multirow[b]{3}{*}{ Subject } & \multicolumn{7}{|c|}{ Minutes after start of glucagon administration (duration of infusion $\mathbf{3 0}$ minutes) } & \multirow{3}{*}{$\begin{array}{c}\text { Relative } \\
\text { assimilation } \\
\text { index } \\
\text { (RAI) }\end{array}$} \\
\hline & \multicolumn{2}{|c|}{30} & \multicolumn{2}{|c|}{55} & \multicolumn{2}{|c|}{80} & 105 & \\
\hline & C* & $\mathrm{vt}$ & C* & $\mathrm{V} \dagger$ & $C^{*}$ & $\mathrm{Vt}$ & $C^{*}$ & \\
\hline
\end{tabular}

\begin{tabular}{|c|c|c|c|c|c|c|c|c|c|}
\hline $\begin{array}{l}\text { J. H. } \\
\text { J. S. } \\
\text { N. D. } \\
\text { F. C. } \\
\text { R. B. } \\
\text { H. S. } \\
\text { D. H. } \\
\text { A. K. } \\
\text { A. B. } \\
\text { J. G. }\end{array}$ & $\begin{array}{l}35 \\
64 \\
39 \\
46 \\
74 \\
41 \\
59 \\
55 \\
60 \\
53\end{array}$ & $\begin{array}{l}29 \\
38 \\
22 \\
31 \\
55 \\
14 \\
54 \\
40 \\
34 \\
33\end{array}$ & $\begin{array}{r}25 \\
31 \\
-19 \\
14 \\
71 \\
2 \\
11 \\
34 \\
47 \\
17\end{array}$ & $\begin{array}{r}-2 \\
7 \\
-20 \\
5 \\
63 \\
-26 \\
0 \\
22 \\
23 \\
-11\end{array}$ & $\begin{array}{r}-18 \\
-16 \\
-26 \\
-99 \\
15 \\
-32 \\
-24 \\
-1 \\
-23 \\
-7\end{array}$ & $\begin{array}{r}-27 \\
-21 \\
-28 \\
-11 \\
13 \\
-41 \\
-26 \\
-6 \\
-24 \\
-14 \\
\text { an an }\end{array}$ & $\begin{array}{l}-12 \\
-25 \\
-8 \\
- \\
-20 \\
-21 \\
-13 \\
-22 \\
-4 \\
\text { ard D }\end{array}$ & $\begin{array}{r}-14 \\
-30 \\
-10 \\
- \\
-24 \\
-18 \\
-14 \\
-23 \\
-5 \\
\text { ation }\end{array}$ & $\begin{array}{r}61.7 \\
54.7 \\
46.2 \\
40.0 \\
23.8 \\
132.6 \\
37.1 \\
32.6 \\
44.9 \\
74.3 \\
54.8 \pm 31.0\end{array}$ \\
\hline
\end{tabular}

Subjects given glucagon intravenously $(0.03 \mathrm{mg} . / \mathrm{Kg}$. body weight) after subcutaneous injection

\begin{tabular}{|c|c|c|c|c|c|c|c|c|c|}
\hline \multicolumn{10}{|c|}{ - } \\
\hline $\begin{array}{l}\text { J. H. } \\
\text { J. S. } \\
\text { N. D. } \\
\text { F. C. } \\
\text { R. B. } \\
\text { H. S. } \\
\text { D. H. } \\
\text { A. K. } \\
\text { A. B. } \\
\text { J. G. }\end{array}$ & $\begin{array}{l}59 \\
84 \\
63 \\
78 \\
77 \\
58 \\
88 \\
68 \\
76 \\
96\end{array}$ & $\begin{array}{l}64 \\
82 \\
64 \\
80 \\
69 \\
57 \\
75 \\
70 \\
73 \\
96\end{array}$ & $\begin{array}{r}66 \\
92 \\
73 \\
110 \\
96 \\
59 \\
120 \\
89 \\
86 \\
76\end{array}$ & $\begin{array}{r}74 \\
92 \\
65 \\
111 \\
88 \\
61 \\
111 \\
93 \\
84 \\
74\end{array}$ & $\begin{array}{r}11 \\
36 \\
20 \\
82 \\
64 \\
18 \\
80 \\
67 \\
-\quad 2 \\
36\end{array}$ & $\begin{array}{r}10 \\
35 \\
11 \\
86 \\
55 \\
22 \\
75 \\
71 \\
-4 \\
35 \\
\text { an an }\end{array}$ & $\begin{array}{r}-20 \\
0 \\
-\quad 2 \\
60 \\
23 \\
0 \\
38 \\
-31 \\
6 \\
\text { ard } \mathrm{D}\end{array}$ & $\begin{array}{r}-14 \\
1 \\
-\quad 5 \\
65 \\
23 \\
4 \\
35 \\
-34 \\
8 \\
\text { ation }\end{array}$ & $\begin{array}{r}8.8 \\
9.4 \\
17.9 \\
2.1 \\
9.6 \\
14.1 \\
10.4 \\
0.9 \\
13.0 \\
7.9 \\
9.4 \pm 5.1\end{array}$ \\
\hline
\end{tabular}

Subjects given epinephrine subcutaneously $(0.003 \mathrm{mg} . / \mathrm{Kg}$. body weight)

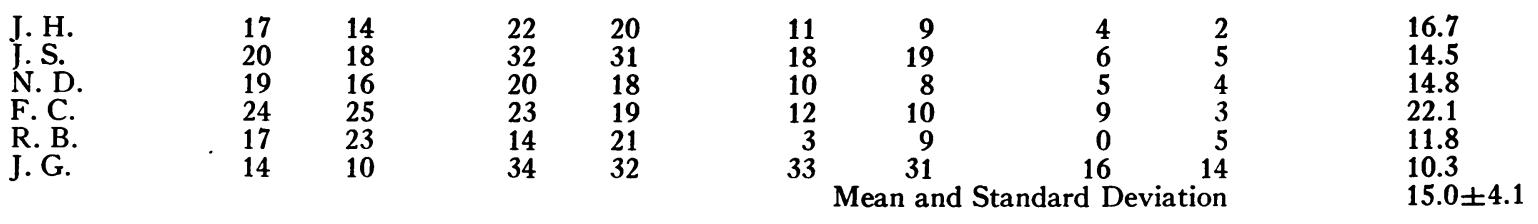

* Capillary glucose increments over control value, in $\mathrm{mg}$. per $100 \mathrm{ml}$.

† Venous glucose increments over control value, in $\mathrm{mg}$. per $100 \mathrm{ml}$.

The over-all response of the patients with liver disease is discernibly different. The slower rise, the somewhat lower, late peak, and the slower descent of the curve all are distinguishing features. Although the curves have different configurations, consideration of the standard deviations of the individual means shows that there is considerable overlap between the two groups.

The hyperglycemic responses (venous) of the same normal subjects and the same patients with liver disease given the same quantity of glucagon at the same rate but following pre-treatment with epinephrine are compared in Figure 3. By this modification of the procedure, the overlap between the patients with liver disease and the normal sub- jects has been eliminated and the difference between the responses of the two groups becomes striking.

When glucagon alone is administered (Figure 2) the difference between the means of the responses (venous blood glucose) of normal subjects and patients with hepatic disease enters the 0.01 range of statistical significance only at one point, 50 minutes after cessation of glucagon infusion. When glucagon and epinephrine are administered together (Figure 3) the differences between the normal group and the liver-disease group at the end of the glucagon infusion and at the peak of the curve are of a high order of statistical significance $(p<0.001)$. 
TABLE III

Effect of glucagon alone and glucagon and epinephrine together on venous glucose levels in patients with liver disease

\begin{tabular}{lcccc}
\hline & \multicolumn{4}{c}{$\begin{array}{c}\text { Minutes after start of glucagon administration } \\
\text { (duration of infusion }\end{array}$} \\
\cline { 2 - 6 } Patient & 30 & 55 & 80 & 105 \\
& $\mathrm{~V}^{*}$ & $\mathrm{~V}^{*}$ & $\mathrm{~V}^{*}$ & $\mathrm{~V}^{*}$ \\
\hline
\end{tabular}

Patients given glucagon intravenously (0.03 mg./Kg. body weight)

$\begin{array}{lrrrr}\text { H. R. } & 9 & 19 & 21 & 14 \\ \text { G. F. } & 21 & 41 & & -7 \\ \text { M. G. } & 43 & 40 & 17 & -7 \\ \text { A. C. } & 15 & 21 & 13 & -1 \\ \text { E. E. } & 13 & 11 & 6 & -15 \\ \text { H. C. } & 23 & 24 & -2 & -8 \\ \text { A. G. } & 4 & 2 & -3 & -25 \\ \text { J. F. } & 17 & 18 & -3 & \end{array}$

Patients given glucagon intravenously $(0.03 \mathrm{mg} . / \mathrm{Kg}$. body weight) after subcutaneous injection of epinephrine ( $0.003 \mathrm{mg}$. $/ \mathrm{Kg}$. body weight)

$\begin{array}{lrrrr}\text { H. R. } & 14 & 29 & 41 & \\ \text { G. F. } & 21 & 42 & & \\ \text { M. G. } & 40 & 53 & 36 & 19 \\ \text { A. C. } & 24 & 37 & 28 & 10 \\ \text { E. E. } & 4 & 5 & 6 & 7 \\ \text { H. C. } & 30 & 32 & 8 & -25 \\ \text { A. G. } & 9 & 11 & 2 & -5 \\ \text { J. F. } & 13 & 8 & 6 & 5\end{array}$

* Venous glucose increments over control values, in mg. per $100 \mathrm{ml}$.

\section{DISCUSSION}

When glucagon alone is given to normal subjects, the hyperglycemic responses which ensue are difficult to interpret without consideration of capillary as well as venous glucose values. Reference to Figure 1A and Table II indicates that during and immediately after glucagon administration extrahepatic utilization of the released glucose is continuing at a rapid rate. Hence, it is difficult by means of isolated determinations of venous glucose values to know whether the observed glycemic level is low in a given instance because of rapid glucose uptake by peripheral cells, or because the ability of the liver to store or release glycogen is impaired. ${ }^{7}$ Although more information about these alternative possibilities can be gained from simultaneous determination of capillary and venous glucose in an extremity, serial measurements of both capillary and venous glucose levels are not feasible as a routine clinical procedure.

${ }^{7}$ It is possible that in the cirrhotic liver vascular shunts (22) may of themselves modify the hyperglycemic response to such agents as glucagon and epinephrine.

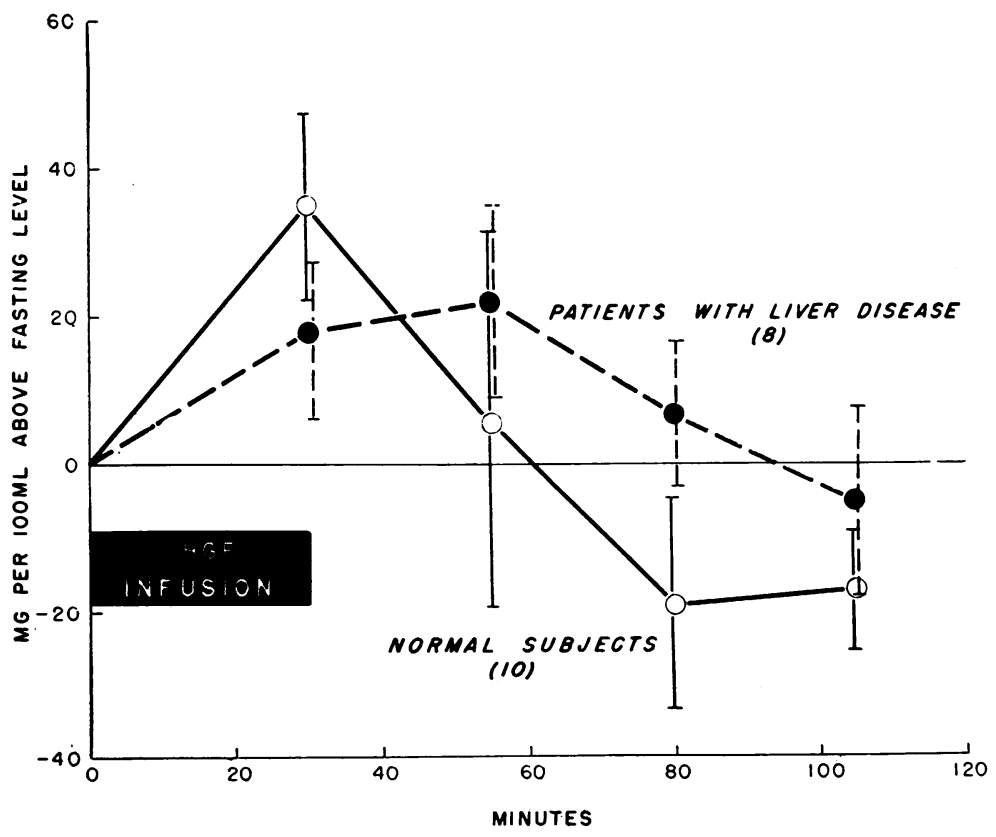

Fig. 2. Comparison of Means of Hyperglycemic Responses (Venous) of Normal Subjects and of Patients with Liver Disease to Glucagon Alone

Vertical bars represent one standard deviation. 


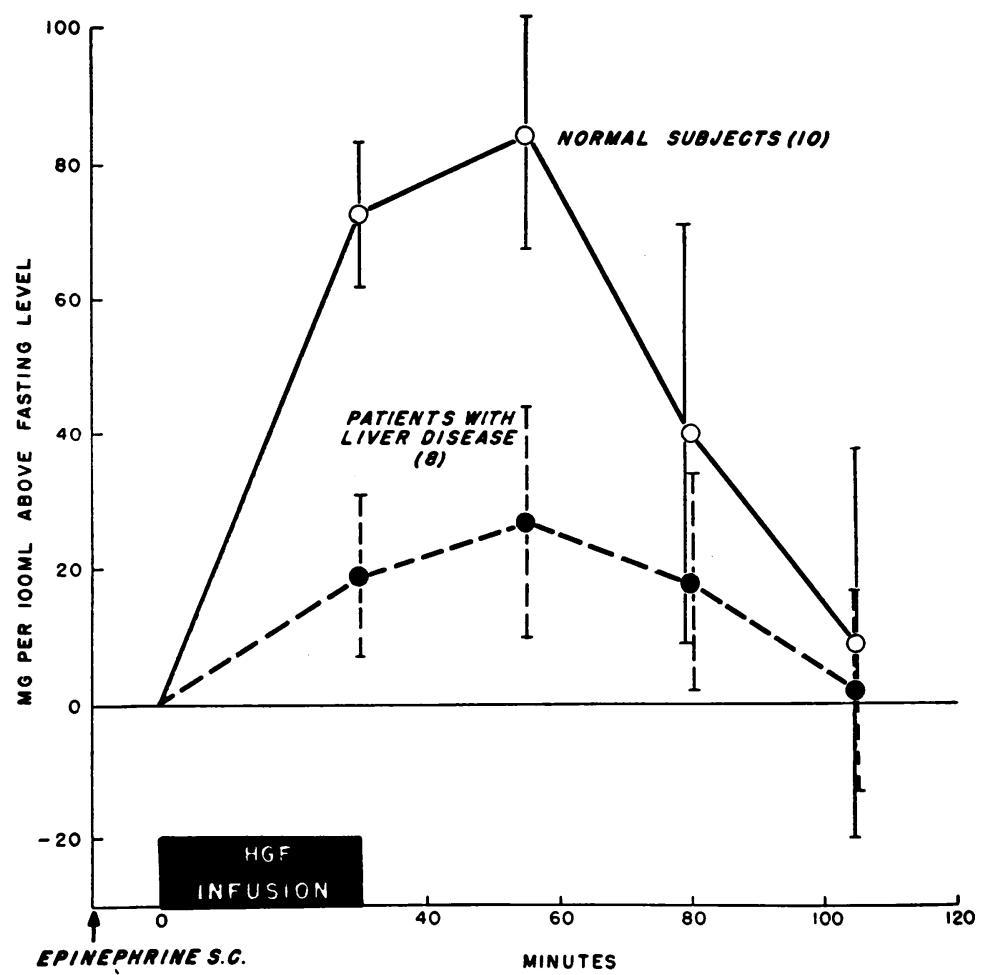

Fig. 3. Comparison of Means of Hyperglycemic Responses (Venous) of Normal Subjects and Patients with Liver Disease to Glucagon and EPINEPHRINE TOGETHER

Vertical bars represent one standard deviation.

Comparison of the hyperglycemic responses to glucagon of normal subjects and liver patients (Figure 2 and Tables II and III) indicates that although the mean curves of the two groups differ in pattern, the differences between the means approach statistical significance only at two points. In view of the severity of the liver damage in the patient group such differences cannot be regarded as satisfactory since patients with moderate or minimal hepatic disease could be expected to show even less distinctive responses to glucagon. Hence, glucagon-induced hyperglycemia, as such, does not appear to be a useful index of liver function.

The peripheral uptake studies performed on the normal subjects during and after glucagon administration indicate that the venous glucose values which occur during the hyperglycemic phase of the response to glucagon represent a resultant of two activities taking place simultaneously. These are (a) release of glucose from the liver, and (b) uptake of glucose by extrahepatic cells. Previous studies by the Coris (23), and others (21, 24,
25), have suggested that epinephrine acts to inhibit glucose uptake by peripheral cells. Hence, in a second series of experiments, epinephrine was administered in conjunction with glucagon to determine whether, by this means, the complicating variable of peripheral glucose utilization might be minimized. That this was accomplished is indicated by the greatly diminished relative assimilation indexes associated with administration of epinephrine along with glucagon (Table II). The modifying effect of epinephrine upon the pattern of $\mathrm{C}-\mathrm{V}$ differences of glucagon-induced hyperglycemia is shown in part $B$ of Figure $1 .^{8}$

8 If, as postulated, epinephrine has an inhibitory effect on peripheral utilization of glucose, one would expect that the hyperglycemic peaks obtained in normal subjects when glucagon and epinephrine are given together would be higher than could be accounted for by simple addition of the hyperglycemic responses of the same subjects to glucagon and epinephrine individually. (Even the assumption that there is an additive effect may be unwarranted [2].) Actually, in five of the six normal subjects whose responses to glucagon alone, glucagon and epinephrine together and epinephrine alone were 
Comparison of the normal and liver-disease groups in terms of their responses to the glucagon and epinephrine combination (Figure 3 ) discloses differences between the two sets of means which attain a high order of statistical significance at the end of glucagon infusion and at the peak of the curve. Thus, administration of a small (nontoxic) dose of epinephrine along with glucagon reduces the modifying effect of peripheral utilization upon the venous and capillary glucose levels and permits a far better distinction to be made between the response to glucagon of normal subjects and patients with liver disease.

Although glucagon-induced hyperglycemia per $s e$ is clearly not a satisfactory index of liver function, measurement of the peripheral hyperglycemia induced by a combination of epinephrine and glucagon appears to be the best clinical method available (short of hepatic vein catheterization) for estimating the ability of the liver to store and release glycogen. Therefore, it has potential value as a test of liver function. Loeb, Reeves, and Glasier (11) have pointed out the lack of specificity of the hyperglycemic response to epinephrine, noting that patients with such "non-hepatic" disorders as carcinoma of the pancreas and diabetes mellitus also display an abnormally low rise in blood glucose following epinephrine administration. However, these authors did not record carbohydrate intakes prior to the time the epinephrine test was performed. Control of this dietary factor presumably would enhance specificity of the hyperglycemic response induced by such agents as epinephrine and glucagon.

Whether glucagon-epinephrine hyperglycemia will provide useful information about liver function which is not readily obtainable by means of existing tests now in wide use can be determined only after prolonged and detailed comparative studies.

\section{SUMMARY AND CONCLUSIONS}

Highly purified glucagon was administered intravenously to ten normal subjects and eight pa-

studied, the glucagon-epinephrine-induced hyperglycemia was higher, usually by a considerable margin, than the sum of the hyperglycemias, respectively, induced by epinephrine alone and glucagon alone. This finding provides further support for the view that epinephrine has an inhibitory effect on peripheral glucose utilization. tients with parenchymal liver disease. Blood glucose levels were measured before, during, and after glucagon infusion. On a second occasion, the experimental procedure was repeated in the same normal subjects and patients except that a small quantity of epinephrine was administered subcutaneously 10 minutes prior to glucagon infusion. On a third occasion, the effect of the same quantity of epinephrine alone on capillary and venous glucose levels in six of the normal subjects was determined.

Although the curves representing the mean hyperglycemic response (venous) of the two groups to glucagon alone differed appreciably in configuration, the standard deviations of the individual means showed considerable overlap. Accordingly, it is believed that glucagon-induced hyperglycemia per se has little value as an index of liver function.

When epinephrine was administered prior to glucagon infusion in an attempt to minimize the complicating effect of extrahepatic glucose removal on venous glucose levels, the overlap between the responses of the normal subjects and the patients with hepatic disease was removed and the difference between the two groups became striking. Thus, it appears that glucagon-epinephrine-induced hyperglycemia has potential value as an index of one aspect of liver function.

\section{ACKNOWLEDGMENT}

The authors wish to thank Dr. Mary C. Morgan and Dr. Louis B. Dotti for their valuable assistance in carrying out these studies.

\section{REFERENCES}

1. Collens, W. S., and Murlin, J. R., Hyperglycemia following the portal injection of insulin. Proc. Soc. Exper. Biol. \& Med., 1929, 26, 485.

2. Sutherland, E. W., and Cori, C. F., Effect of hyperglycemic-glycogenolytic factor and epinephrine on liver phosphorylase. J. Biol. Chem., 1951, 188, 531.

3. Myers, J. D., Kibler, R. F., and Taylor, W. J., Effects of pancreatic hyperglycemic factor on hepatic carbohydrate metabolism of man. Federation Proc., 1952, 11, 111.

4. Sutherland, E. W., The effect of the hyperglycemic factor and epinephrine on enzyme systems of liver and muscle. Ann. New York Acad. Sc., 1951, 54, 693.

5. Kirtley, W. R., Waife, S. O., Helmer, O. M., and Peck, F. B., Effect of purified glucagon (hyperglycemic-glycogenolytic factor, HGF) on carbo- 
hydrate and corticoid metabolism in normal and diabetic subjects. Diabetes, 1953, 2, 345.

6. Drury, D. R., Wick, A. N., and Sherrill, J. W., The effect of the hyperglycemic factor on the metabolism of glucose by the extrahepatic tissues. Diabetes, 1954, 3, 129.

7. Root, M. A., Ellis, J., and Staub, A., Effect of glucagon on insulin hypoglycemia. Proc. Soc. Exper. Biol. \& Med., 1954, 85, 507.

8. Ingle, D. J., Nezamis, J. E., and Humphrey, L. M., Absence of hyperglycemic effect of glucagon in the eviscerate rat. Proc. Soc. Exper. Biol. \& Med., 1953, 84, 232.

9. Van Itallie, T. B., Morgan, M. C., and Dotti, L. B., Effect of glucagon on peripheral utilization of glucose in man. J. Clin. Endocrinol. \& Metab., 1955, 15, 28.

10. Brill, S., and Fitz-Hugh, T., Jr., Epinephrine glycogenolysis as a test of liver function. Arch. Path., 1928, 5, 1148.

11. Loeb, R. F., Reeves, E. B., and Glasier, H. P., Responses to the injection of epinephrine in hepatic disease. J. Clin. Invest., 1931, 10, 19.

12. Goodman, L. S., and Gilman, A., The Pharmacological Basis of Therapeutics; A Textbook of Pharmacology, Toxicology and Therapeutics for Physicians and Medical Students. 2nd ed., New York, The Macmillan Co., 1955, p. 494.

13. DeDuve, C., Glucagon, the hyperglycæmic glycogenolytic factor of the pancreas. Lancet, 1953, 2, 99.

14. Staub, A., Sinn, L., and Behrens, O. K., Purification and crystallization of hyperglycemic glycogenolytic factor (HGF). Science, 1953, 117, 628.

15. Conn, J. W., Interpretation of the glucose tolerance test. The necessity of a standard preparatory diet. Am. J. M. Sc., 1940, 199, 555.
16. Somogyi, M., A new reagent for the determination of sugars. J. Biol. Chem., 1945, 160, 61.

17. Somogyi, M., Determination of blood sugar. J. Biol. Chem., 1945, 160, 69.

18. Nelson, N., A photometric adaptation of the Somogyi method for the determination of glucose. J. Biol. Chem., 1944, 153, 375.

19. Foster, G. L., Studies on carbohydrate metabolism. I. Some comparisons of blood sugar concentrations in venous blood and in finger blood. J. Biol. Chem., 1923, 55, 291.

20. Langner, P. H., Jr., and Fies, H. L., Blood sugar values of blood obtained simultaneously from the radial artery, antecubital vein and the finger. Am. J. Clin. Path., 1942, 12, 559.

21. Somogyi, M., Studies of arteriovenous differences in blood sugar. V. Effect of epinephrine on the rate of glucose assimilation. J. Biol. Chem., 1950, 186, 513.

22. Mann, J. D., Wakim, K. G., and Baggenstoss, A. H., The vasculature of the human liver: A study by the injection-cast method. Proc. Staff Meet., Mayo Clin., 1953, 28, 227.

23. Cori, C. F., and Cori, G. T., The mechanism of epinephrine action. III. The influence of epinephrine on the utilization of absorbed glucose. J. Biol. Chem., 1928, 79, 343.

24. Amatuzio, D. S., Schultz, A. L., Vanderbilt, M. J., Rames, E. D., and Nesbitt, S., The effect of epinephrine, insulin, and hyperthyroidism on the rapid intravenous glucose tolerance test. $\mathrm{J}$. Clin. Invest., 1954, 33, 97.

25. Ingle, D. J., and Nezamis, J. E., The effect of epinephrine upon the glucose tolerance and work performance of the eviscerate rat. Endocrinology, 1950, 46, 14. 